the grave concerns and potential dangers concerning the clinical practice of euthanasia, we strongly believe in scientific evidence as important in informing the juridical, philosophical, political, societal and ethical arguments in this debate. This provides a sound basis both to legitimately question euthanasia and provide sufficient built-in safeguards to protect against potential abuses.

1 Dierickx S, Deliens L, Cohen J, Chambaere K. Euthanasia for people with psychiatric disorders or dementia in Belgium: analysis of officially reported cases. BMC Psychiatry 2017; 17: 203

2 Verhofstadt $M$, Thienpont L, Peters G-JY. When unbearable suffering incites psychiatric patients to request euthanasia: qualitative study. $\mathrm{Br} J$ Psychiatry 2017; 211: 238-45.

3 Dees $M$, Vernooij-Dassen $M$, Dekkers $W$, van Weel $C$. Unbearable suffering of patients with a request for euthanasia or physician-assisted suicide: an integrative review. Psychooncology 2010; 19: 339-52.

4 Ministry of Justice. Law on euthanasia of May 28, 2002 [in Dutch and French], Belgian Official Gazette, 2002; 22 June (http://www.npzl.be/files/ 107a_B3_wet_euthanasie.pdf).

M. Verhofstadt, End-of-Life Care Research Group, Vrije Universiteit Brussel (VUB) and Ghent University, Belgium; L. Thienpont, Co-founder of and psychiatrist at Vonkel (an end-of-life consultation centre), Ghent, Belgium; G.-J. Y. Peters, Vonkel (an end-of-life consultation centre), Ghent, Belgium; G.-J. Y. Peters,
Department of Methodology and Statistics, Faculty of Psychology and Education Science, Open University of the Netherlands, Heerlen, The Netherlands; K. Chambaere, End-of-Life Care Research Group, Vrije Universiteit Brussel (VUB) \& Ghent University, Belgium. Email: monica.verhofstadt@gmail.com

doi: $10.1192 / \mathrm{bjp} .211 .6 .397 \mathrm{~b}$

\section{The Pool judgment has not changed the law of expert evidence}

We are concerned that the editorial by Series \& Herring ${ }^{1}$ is likely falsely to give readers the impression that the Pool judgment represents a change in the law of expert evidence. The judgment has not changed the law in any way. And we would advise doctors who work, or wish to work, as experts should read the detailed analysis of the current law concerning the definition, in law, of expertise recently published in BJPsych Advances. ${ }^{2}$ This includes a review of the seminal cases, and also some other recent relevant judgments, none of which is referred to in the editorial. Psychiatrists undertaking expert witness practice should also refer to the Royal College of Psychiatrists' College Report CR193, ${ }^{3}$ soon to be amended after discussions with professional and regulatory authorities so as to make the law as clear as possible to experts.

1 Series $\mathrm{H}$, Herring J. Doctor in court: what do lawyers really need from doctors, and what can doctors learn from lawyers? Br J Psychiatry 2017; 211: 135-6.

2 Rix K, Haycroft A, Eastman N. Danger in deep water or just ripples in the pool: has the Pool judgment changed the law on expert evidence? BJPsych Adv 2017; 23: 347-57.

3 Rix K, Eastman N, Adshead G. Responsibilities of Psychiatrists Who Provide Expert Opinion to Courts and Tribunals (College Report CR193). Royal College of Psychiatrists, 2015.

Keith J. B. Rix, Honorary Consultant Forensic Psychiatrist, Norfolk and Suffolk NHS Foundation Trust, Visiting Professor of Medical Jurisprudence, School of Medicine, University of Chester; Nigel Eastman, Barrister-at-Law and Emeritus Professor of Law and Ethics in Psychiatry and Honorary Consultant Forensic Psychiatrist, St George's University of London; Anthony Haycroft, Barrister-at-Law, Serjeants Inn Chambers; Gwen Adshead, Forensic Psychiatrist and Psychotherapist, Southern Health Foundation Trust and Central \& North West London NHS Foundation Trust. Email: keith@drkeithrix.co.uk

doi: 10.1192/bjp.211.6.398

Authors' reply: We are grateful to Dr Rix and colleagues for pointing out to those who might misread our editorial ${ }^{1}$ that the Pool case has not changed the law of expert evidence, although we find it difficult to see how our brief reference to the case of Pool could be seen as misleading. They refer to their own very helpful analysis of recent case law on expert evidence in the September issue of BJPsych Advances, ${ }^{2}$ which, unfortunately, had not been published at the time our editorial went to press.

Readers who would like a full and scholarly account of the law on expert evidence are referred to Hodgkinson \& James, ${ }^{3}$ although even the most recent edition (2015) was not able to include discussion of Squire and Pool. We look forward with much interest not only to the publication of Rix et al's further article in Advances, but also to the revision of CR193, the College's guidance on the responsibilities of experts. All of us who give expert evidence are of course also required to take note of the relevant GMC guidance. ${ }^{4}$

1 Series $\mathrm{H}$, Herring J. Doctor in court: what do lawyers really need from doctors, and what can doctors learn from lawyers? Br J Psychiatry 2017; 211: 135-6.

2 Rix K, Haycroft A, Eastman N. Danger in deep water or just ripples in the pool: has the Pool judgment changed the law on expert evidence? BJPsych Advances 2017; 23: 347-57.

3 Hodgkinson T, James M. Expert Evidence: Law and Practice (4th edn). Sweet and Maxwell, 2015.

4 General Medical Council. Giving Evidence as an Expert Witness. GMC, 2017 (http://www.gmc-uk.org/guidance/ethical_guidance/21193.asp).

Hugh Series, Oxford Health NHS Foundation Trust and Faculty of Law, University of Oxford, Oxford, UK; Jonathan Herring, Faculty of Law, University of Oxford, Oxford, UK. Email: hugh.series@oxep.co.uk

doi: 10.1192/bjp.211.6.398a

\section{Conflating sexual orientation and gender identity}

It is ironic that an editorial which highlights the lack of knowledge of lesbian, gay, bisexual and transgender (LGBT) issues among healthcare professionals should open with a sentence that conflates sexual orientation with gender identity. ${ }^{1}$ Using 'heterosexual' as a contrast to LGBT is inaccurate, as any number of trans heterosexual individuals could attest to. In their discussion of Miranda-Mendizábal et al's paper, ${ }^{2}$ Meader \& Chan make it clear that the paper only covers LGB youth, and that differing sexual orientations within this group may lead to differing experiences; however, in the rest of their editorial 'LGBT youth' is treated as a monolithic entity. For example, Public Health England has two toolkits on suicide prevention in sexual minority groups, one for LGB individuals and one for transgender individuals, in recognition of the different needs of these groups (www.gov.uk/ government/publications/preventing-suicide-lesbian-gay-andbisexual-young-people), rather than a single LGBT toolkit as suggested in the editorial.

It is also perhaps disappointing that the first suggestion of why transgender young people have a greater risk of suicidality is 'higher rates of stigma'. Although this is undoubtedly important, there is increasing evidence that supporting transgender young people to live and present as their gender identity improves mental health outcomes. For example, Olson et al found that transgender children who were supported in their gender identities had rates of depression the same as their cisgender peers, rather than the much higher rates of depression previously reported for transgender children living as their birth-assigned gender. ${ }^{3}$ In this context, the waiting times for gender identity clinics (GICs) should be highlighted. For many in the UK, this is more than a year: for example, the Tavistock GIC currently gives a waiting time of 14 months from referral to first appointment (https://gic.nhs.uk/appointments/waiting-times). In fact, many 